\title{
PERBEDAAN MEDIA POSTER DAN KARIKATUR TERHADAP KETERAMPILAN MENULIS PADA SISWA KELAS III DI MIS DAARUL MUQIMIEN
}

\author{
${ }^{1}$ Erdhita Oktrifianty, ${ }^{2}$ Rolisti Amelia \\ ${ }^{1,2}$ Universitas Muhammadiyah Tangerang \\ e-mail: ${ }^{1}$ erdhitaoktrifianty@gmail.com, ${ }^{2}$ rolistiamelia15@gmail.com
}

\begin{abstract}
Abstrak
Penelitian ini adalah penelitian kuantitatif, dengan jenis penelitian Quasi Eksperimen. Populasinya adalah seluruh siswa kelas III di MIS Daarul Muqimien. Sampel penelitian ini adalah 15 siswa kelas III-A (Kelas Eksperimen I yang diajarkan dengan media pembelajaran poster) dan 15 siswa kelas III-B (Kelas Eksperimen II yang diajarkan dengan media pembelajaran karikatur). Analisis data dilakukan dengan Uji-t. Temuan ini menunjukkan bahwa: (1) Hasil belajar siswa yang diajarkan dengan media pembelajaran karikatur lebih baik dengan nilai rata-rata 78,73 daripada hasil belajar siswa yang diajarkan dengan media pembelajaran karikatur dengan nilai rata-rata 73,73 (2) Terdapat perbedaan yang signifikan hasil belajar siswa yang diajarkan dengan media pembelajaran poster dan karikatur terhadap keterampilan menulis pada materi menulis karangan deskripsi di kelas III MIS Daarul Muqimien tahun pelajaran 2020/2021. Hal ini sesuai dengan perhitungan uji t, bahwa berdasarkan hasil perhitungan diperoleh thitung $=6,970$ hasil ini dibandingkan dengan ttabel pada taraf nyata $\alpha=0,05$ dan $\mathrm{dk}=28$ yaitu ttabel $=1,70$ maka thitung $>$ ttabel $=6,970>1,70$. Simpulan penelitian ini menjelaskan bahwa terdapat perbedaan yang signifikan hasil belajar siswa yang diajarkan dengan media pembelajaran poster dan karikatur terhadap keterampilan menulis pada materi menulis karangan deskripsi di kelas III MIS Daarul Muqimien tahun pelajaran 2020/2021.
\end{abstract}

Kata kunci : Keterampilan Menulis, Media Poster dan Karikatur

\begin{abstract}
This research is a quantitative research, with the type of research is Quasi Experiment. The population is all third graders in MIS Daarul Muqimien. The samples of this study were 15 students in class III-A (Experimental Class I taught with poster learning media) and 15 students in class III-B (Experimental Class II taught with caricature learning media). Data analysis was performed by t-test. These findings indicate that: (1) The learning outcomes of students taught with caricature learning media are better with an average score of 78.73 than students' learning outcomes taught by caricature learning media with an average value of 73.73 (2) There are differences which is significant in student learning outcomes taught with posters and caricature learning media on writing skills in descriptive essay writing material in class III MIS Daarul Muqimien for the 2020/2021 school year. This is in accordance with the t-test calculation, that based on the calculation results obtained tcount $=6.970$ this result is compared with ttable at the real level $=0.05$ and $d k=28$, namely ttable $=$ 1.70 then tcount $>$ ttable $=6.970>1.70$. The conclusion of this study explains that there is a significant difference in student learning outcomes taught by poster and caricature learning media on writing skills in descriptive essay writing material in class III MIS Daarul Muqimien in the 2020/2021 school year.
\end{abstract}

Keywords: Writing Skill, Poster Media, Caricature 


\section{PENDAHULUAN}

Pendidikan merupakan kebutuhan manusia. Pendidikan selalu mengalami perkembangan dan perbaikan sesuai dengan perkembangan disegala bidang kehidupan. Pendidikan sangat dibutuhkan dalam kelangsungan dan kesejahteraan hidup seseorang bahkan dalam kesejahteraan suatu bangsa. Pendidikan memiliki peran penting dalam upaya peningkatan sumber daya manusia kearah yang lebih baik. Pendidikan diharapkan mampu membentuk peserta didik yang dapat mengembangkan sikap, keterampilan, dan kecerdasan intelektualnya agar menjadi manusia yang terampil, cerdas, serta berakhlak mulia.

Kurikulum pendidikan sekolah dasar terdapat beberapa mata pelajaran pokok yang harus dikuasai peserta didik. Salah satunya adalah Bahasa Indonesia yang sangat berperan penting dalam proses pendidikan. Dalam pembelajaran Bahasa Indonesia terdapat empat aspek keterampilan yaitu menyimak, membaca, berbicara, dan menulis. Salah satu keterampilan bahasa adalah menulis.

Menulis merupakan salah satu keterampilan berbahasa yang dipergunakan untuk berkomunikasi secara tidak langsung, tidak secara tatap muka dengan orang lain. Keterampilan menulis perlu ditanamkan sejak dini kepada siswa sekolah dasar. Dengan memiliki kemampuan menulis, berpikir kreatif dan lritis siswa dapat berkembang dan mempertajam kepekaan perasaan, penalaran, serta kepekaan anak terhadap masalah kemanusiaan.

Secara keseluruhan pelajaran menulis di Sekolah Dasar (SD) mempunyai kedudukan yang sangat penting sebagai upaya melatih siswa agar terlatih dan terampil menulis. Namun kenyataannya, banyak siswa yang menganggap bahwa keterampilan menulis adalah satu beban, menunda-nunda menyelesaikan tugas menulisnya. Bahkan yang paling parahnya adalah siswa telah diajarkan menulis tetapi masih banyak ditemukan siswa yang tidak kompeten dalam menulis.

Rendahnya keterampilan menulis diduga oleh beberapa faktor yaitu dari terkait menerapkan pada model pemaparan konsep yang diikuti pemberian beberapa contoh, catatan, penugasan di papan tulis serta kurang memberikan variasi dalam pembelajarannya. Dalam proses belajar mengajar, ada dua unsur yang amat penting adalah metode mengajar dan media pembelajran. Guru perlu menerapkan suatu metode yang dapat memberikan semangat baru bagi anak-anak agar lebih kreatif, yaitu dengan menggunakan media pendidikan pada siswa 
dapat tercapai. Kunci sukses pengajaran bukan terletak pada kecanggihan kurikulum atau kelengkapan fasilitas sekolah, melainkan tingkat kredibilitas seorang guru dalam mengatur dan memanfaatkan media yang ada didalam kelas.

Febriandari, dkk (2016) menambahkan bahwa rendahnya kemampuan menulis siswa disebabkan 1) kurangnya media yang disediakan, 2) siswa hanya menerima pembelajaran menulis dari ceramah guru tanpa adanya media visual yang membantu siswa untuk belajar menulis dan memahami cerita, 3) pada proses pembelajaran guru tidak menggunakan model pembelajaran yang inovatif dan sesuai dengan kebutuhan siswa pada materi menulis cerita, sehingga guru perlu berupaya dalam mengembangkan media dan menggunakan model pembelajaran yang inovatif dengan maksud agar tujuan pembelajaran dapat tercapai khususnya dalam pembelajaran menulis cerita.

Penggunaan media sangat penting kehadirannya dalam kegiatan pembelajaran. Minimnya penggunaan media oleh guru selama ini perlu diubah sedikit demi sedikit. Hal ini dimaksudkan agar siswa tidak hanya tinggi kualitias teoritisnya tetapi juga tinggi kualitas praktisnya. Menurut Tarigan dalam Syahrudin (2017) bahwa menulis melalui media gambar merupakan satu teknik pengajaran menulis yang sangat dianjurkan oleh para ahli. Gambar yang kelihatan diam sebenarnya banyak berkata bagi mereka yang peka dan penuh imajinasi.

Pembelajaran menulis selama ini siswa hanya dijejali teori-teori tentang menulis, cara dan ketentuan menulis tetapi teori tersebut tidak dipraktikkan. Hal ini menyebabkan pelaksanaan pembelajaran menulis kurang efektif yakni guru memberikan tugas membuat iklan dan gambar yang disertai dengan tulisan sebagai sebuah informasi dan promosi dengan tema yang sama. Metode pembelajaran seperti itu, membuat siswa menjadi cepat bosan dengan pembelajaran menulis, khususnya menulis dalam menulis iklan seperti poster dan gambar yang disertai tulisan seperti karikatur.

Dari uraian di atas, salah satu media pembelajaran yang diduga cocok diterapkan dalam pembelajaran keterampilan menulis, yaitu media pembelajaran poster. Poster merupakan salah satu dari media visual bisa berperan penting dalam mencegah perilaku yang kurang baik. Sesuai dengan pengertian poster yang merupakan media yang digunakan untuk menyampaikan informasi, saran, atau ide-ide tertentu, sehingga dapat merangsang keinginan yang melihatnya untuk melaksanakan isi tersebut. Hal ini juga diperkuat dengan hasil penelitian dari Hildayanti, dkk (2018) bahwa penggunaan media poster dalam menulis karangan berpengaruh terhadap hasil belajar Bahasa Indonesia. 
Indonesian Journal of Elementary Education

Vol. 1, No.2, Juli 2021

E-ISSN: 2722-6689

http://jurnal.umt.ac.id/index.php/IJOEE

Sedangkan media pembelajaran karikatur merupakan suatu media yang dapat membantu peserta didik mengurangi lamanya waktu mencari ide dan mengurangi kesulitan mengungkapkan gagasan karena ide atau tema dari karikatur lebih jelas, munculnya ide-ide baru dalam pengembangan karangan jauh lebih banyak, dan peserta didik sudah mendapat gambaran tentang apa yang akan diulas. Hal ini juga diperkuat dengan hasil penelitian dari Parendra, dkk (2013) bahwa pemanfaatan media karikatur dapat meningkatkan keterampilan menulis karangan narasi pada siswa Sekolah Dasar.

Berdasarkan paparan di atas terlihat pentingnya penggunaan media pembelajaran yang bervariasi dan menyenangkan dalam meningkatkan kemampuan menulis siswa, peneliti akan melakukan penelitian tentang perbedaan media poster dan karikatur terhadap keterampilan menulis pada siswa kelas III MIS Daarul Muqimien yang berjudul “Perbedaan Media Pembelajaran Poster dan Karikatur Terhadap Keterampilan Menulis Siswa Kelas III Di MIS Daarul Muqimien".

\section{DESKRIPSI TEORI}

Tarigan (2015) berpendapat bahwa "Keterampilan merupakan sesuatu yang berhubungan erat dengan proses-proses yang mendasari bahasa. Bahasa seseorang mencerminkan pikirannya di dalam keterampilan seseorang terhadap berbahasa, semakin cerah dan jelas pula jalan pikirannya. Dengan ini keterampilan hanya dapat diperoleh dan dikuasai dengan jalan praktik dan banyak melakukan pelatihan. Melatih keterampilan berarti melatih keterampilan berpikir" (h.1). Seseorang mampu mempunyai keterampilan dalam berbahasa, baik bahasa Indonesia ataupun bahasa asing. Bloom berpendapat bahwa "Keterampilan merupakan kualitas proses dari pekerjaan atau kegiatan yang dilakukan oleh mereka yang memiliki pengetahuan dan menggunakan pengetahuan itu untuk menangani masalah atau situasi baru”. (Saleh, 2013, h.26).

Berdasarkan beberapa pendapat di atas dapat disimpulkan bahwa, keterampilan adalah suatu kemampuan yang dimiliki seseorang untuk dapat menyelesaikan segala tugasnya dengan benar dan cepat yang nantinya dapat berkembang menjadi pribadi yang lebih baik dan semakin baik.

Selanjutnya menurut Darwis (2011) berpendapat bahwa menulis merupakan keterampilan berbahasa aktif. Menulis merupakan kemampuan puncak seseorang untuk 
dikatakan terampil berbahasa. Lalu menurut Dalman (2016) menulis merupakan suatu kegiatan komunikasi berupa penyampaian pesan (informasi) secara tertulis kepada pihak lain dengan menggunakan bahasa tulis sebagai alat atau medianya. Aktivitas menulis melibatkan beberapa unsur, yaitu : penulis sebagai penyampaian pesan, isi tulisan, saluran, atau media, dan pembaca.

Cere dalam Yarmi (2020) menyatakan menulis merupakan salah bentuk komunikasi. Selanjutnya dikatakan bahwa di dalam komunikasi terdapat empat unsur, yaitu (1) menulis merupakan bentuk ekspresi diri; (2) menulis merupakan sesuatu yang umum disampaikan ke pembaca; (3) menulis merupakan aturan dan tingkah laku; dan (4) menulis merupakan sebuah cara belajar. Sebagai bentuk dari ekspresi diri, menulis bertujuan untuk mengkomunikasikan, menyampaikan sebuah ide melewati batas waktu dan ruang. Artinya, menulis dapat dilakukan kapan saja, dan di mana saja sesuai dengan keadaan yang terdapat dalam diri penulis.

Dari penjelasan di atas dapat disimpulkan bahwa, keterampilan menulis adalah kemampuan dalam mengungkapkan gagasan dan menyampaikannya melalui bahasa tulis kepada pembaca seperti apa yang dimaksud oleh pengarang.

Menurut Megawati (2017) bahwa poster merupakan salah satu media grafis yang paling tampak kekuatannya sebagai media penyampai pesan. Selanjutnya Sanaky (2015) berpendapat bahwa poster adalah gambar dengan ukuran besar dan memberi tekanan pada satu atau dua ide pokok yang divisualisasikan secara sederhana dan jelas. Media poster yang baik adalah poster yang segera dapat dipahami secara cepat oleh orang yang melihatnya.

Lebih lanjut Prijatna di dalam Kurniawati (2013) mengemukakan bahwa karikatur adalah gambar atau penggambaran suatu objek konkret dengan cara melebih-lebihkan ciri khas objek tersebut, biasanya objek tersebut adalah wajah manusia. Karikatur menggambarkan subjek yang dikenal dan umumnya dimaksudkan untuk menimbulkan kelucuan bagi pihak yang mengenal subjek tersebut. Karikatur dibedakan dari kartun karena karikatur tidak membentuk cerita sebagaimana kartun, namun karikatur dapat menjadi unsur dalam kartun, misalnya dalam kartun editorial.

\section{METODE PENELITIAN}

Penelitian Eksperimen dengan jenis penelitian yang digunakan adalah Penelitian Quasi Eksperimen (eksperimen semu) yaitu salah satu tipe penelitian eksperimen dimana 
Indonesian Journal of Elementary Education

Vol. 1, No.2, Juli 2021

E-ISSN: 2722-6689

http://jurnal.umt.ac.id/index.php/IJOEE

peneliti tidak melakukan randomisasi (randomnes) dalam penentuan subjek kelompok penelitian, namun hasil yang dicapai cukup berarti, baik ditinjau dari validitas internal maupun eksternal (Nuraini, 2018). Penelitian ini bertujuan untuk mengetahui perbedaan media pembelajaran poster dengan karikatur terhadap keterampilan menulis siswa di kelas III MIS Daarul Muqimien Tahun Pelajaran 2020/2021. Desain penelitian ini terdiri dari variabel bebas diklasifikasikan menjadi 2 (dua) sisi, yaitu media pembelajaran poster $\left(\mathrm{X}_{1}\right)$ dan media pembelajaran karikatur $\left(\mathrm{X}_{2}\right)$. Sedangkan variabel terikatnya adalah keterampilan menulis siswa $(\mathrm{Y})$.

Populasi dan sampel yang digunakan adalah seluruh anak kelas III di MIS Daarul Muqimien. Kelas eksperimen I berjumlah 15 orang siswa dan kelas eksperimen II berjumlah 15 orang siswa. Dalam melaksanakan kegiatan penelitian eksperimen ini teknik pengumpulan data yang peneliti lakukan adalah tes menulis karangan deskripsi media poster dan karikatur.

\section{HASIL DAN PEMBAHASAN}

\section{Hasil Belajar Siswa Yang Diajar Dengan Media Pembelajaran Poster $\left(X_{1} Y\right)$}

Hasil belajar pada kelas eksperimen I nilai terendah diperoleh siswa adalah 60 dan nilai tertinggi yang diperoleh siswa adalah 85. Dengan jumlah seluruh nilai siswa pada kelas eksperimen I adalah 1106 dan jumlah sampel adalah 15 siswa, sehingga diperoleh rata-rata pada kelas eksperimen I adalah 73,73 dan Standar Deviasi kelas yaitu 8,40 serta varians 70,49. Rentangan Nilai (Range) 5, banyak kelas 5 dan panjang interval kelas 5. Secara kuantitatif dapat dilihat pada tabel berikut ini:

\section{Tabel 1}

Distribusi Frekuensi Data Hasil Belajar Siswa Yang Diajar Dengan Media Pembelajaran Poster $\left(\mathrm{X}_{1} \mathrm{Y}\right)$ Sebagai Kelas Eksperimen I

\begin{tabular}{|c|c|c|c|c|}
\hline No. & Interval kelas & F absolut & F relatif $(\%)$ & F kumulatif (\%) \\
\hline 1. & $59,5-64,5$ & 2 & 13,33 & 13,33 \\
\hline 2. & $64,5-69,5$ & 2 & 13,33 & 26,66 \\
\hline 3. & $69,5-74,5$ & 3 & 20 & 46,66 \\
\hline 4. & $74,5-79,5$ & 3 & 20 & 66,66 \\
\hline 5. & $79,5-84,5$ & 3 & 20 & 86,66 \\
\hline 6. & $84,5-89,5$ & 2 & 13,34 & 100 \\
\hline \multicolumn{2}{|c|}{ Jumlah } & 15 & 100 & \\
\hline
\end{tabular}

Berdasarkan nilai-nilai tersebut, dapat dibentuk Histogram data kelompok sebagai berikut : 
Gambar 1

Histogram Keterampilan Menulis Siswa Yang Diajar Dengan Media Pembelajaran Poster $\left(\mathbf{X}_{1} \mathbf{Y}\right)$

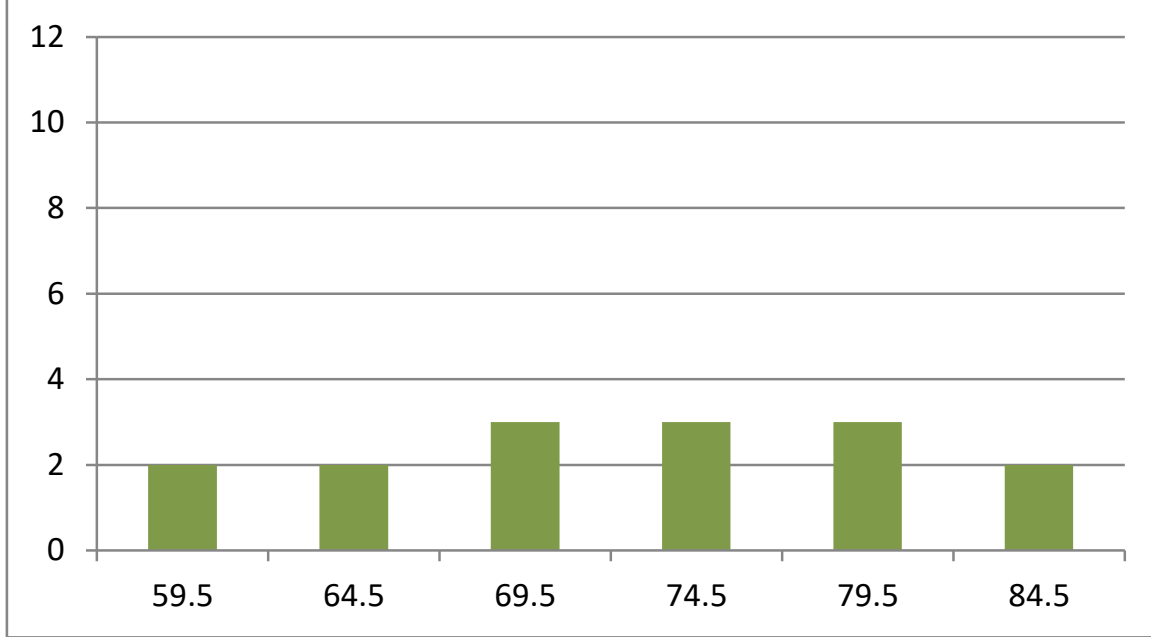

\section{Hasil Belajar Siswa Yang Diajar Dengan Media Pembelajaran Karikatur $\left(\mathrm{X}_{2} \mathrm{Y}\right)$}

Hasil belajar pada kelas eksperimen II menunjukkan bahwa nilai terendah yang diperoleh siswa adalah 65 dan nilai tertinggi yang diperoleh siswa adalah 88. Dengan jumlah seluruh nilai siswa pada kelas eksperimen II adalah 1181 dan jumlah sampel adalah 15 siswa, sehingga diperoleh rata-rata pada kelas eksperimen diperoleh rata-rata pada kelas eksperimen adalah 78,73 dan Standar Deviasi kelas yaitu 7,38 serta varians 54,50. Rentangan Nilai (Range) 5, banyak kelas 5 dan panjang interval kelas 5. Secara kuantitatif dapat dilihat pada tabel berikut ini :

Tabel 2

Distribusi Frekuensi Data Hasil Belajar Siswa yang Diajar dengan media pembelajaran karikatur (X2Y) sebagai Kelas Eksperimen II

\begin{tabular}{|c|c|c|c|c|}
\hline No. & Interval kelas & F absolut & $\mathrm{F}$ relatif $(\%)$ & F kumulatif (\%) \\
\hline 1. & $59,5-64,5$ & 0 & 0 & 0 \\
\hline 2. & $64,5-69,5$ & 2 & 13,33 & 13,33 \\
\hline 3. & $69,5-74,5$ & 1 & 6,67 & 20 \\
\hline 4. & $74,5-79,5$ & 5 & 33,33 & 53,33 \\
\hline 5. & $79,5-84,5$ & 3 & 20 & 73,33 \\
\hline 6. & $84,5-89,5$ & 4 & 26,67 & 100 \\
\hline \multicolumn{2}{|c|}{ Jumlah } & 15 & 100 & \\
\hline
\end{tabular}

Berdasarkan nilai-nilai tersebut, dapat dibentuk Histogram data kelompok sebagai berikut : 
Gambar 2

http://jurnal.umt.ac.id/index.php/lJOEE

Histogram Hasil Belajar Siswa yang Diajar dengan media pembelajaran karikatur $\left(\mathbf{X}_{2} \mathbf{Y}\right)$

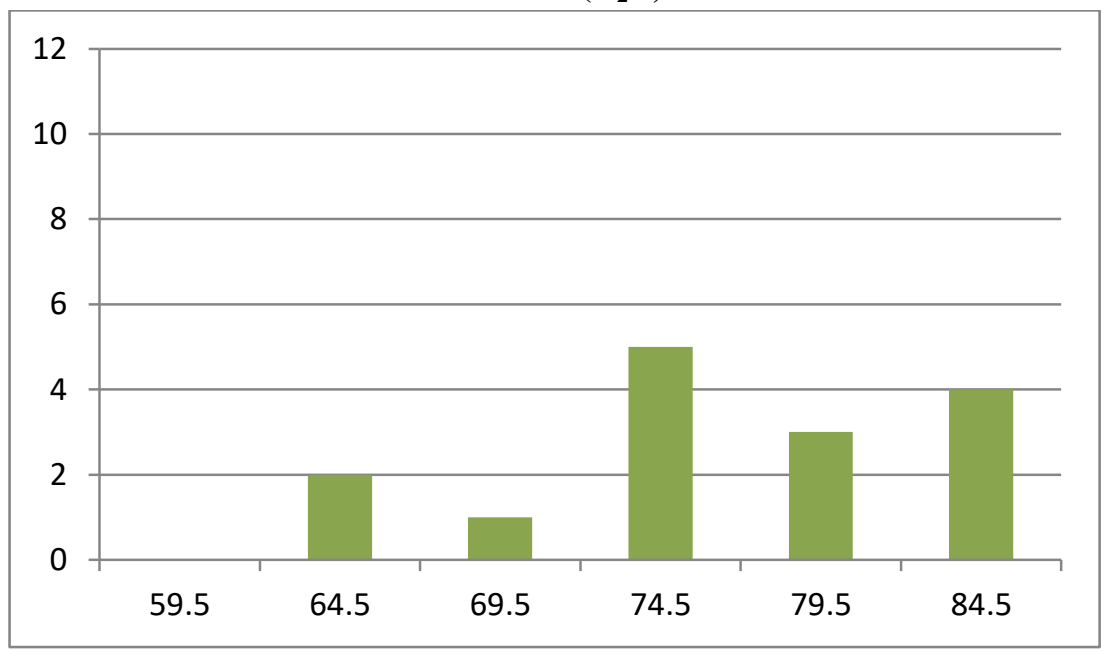

\section{Pengujian Persyaratan Analisis Data}

\section{Uji Normalitas}

Uji normalitas data hasil belajar bahasa indonesia siswa kelas III-A dan kelas IIIB MIS Daarul Muqimien adalah sebagai berikut:

Tabel 3

Rangkuman Hasil Pengujian Normalitas Dengan Uji Lilliefors

\begin{tabular}{|c|c|c|c|}
\hline Kelompok & L-Hitung & L-Tabel & Kesimpulan \\
\hline$X_{1} Y$ & $\mathbf{0 , 1 1 4 5}$ & $\mathbf{0 , 2 2 0}$ & Ho : Diterima, Normal \\
\hline $\mathbf{X}_{2} \mathbf{Y}$ & $\mathbf{0 , 1 0 5 6}$ & $\mathbf{0 , 2 2 0}$ & Ho : Diterima, Normal \\
\hline
\end{tabular}

\section{Uji Homogenitas}

Uji homogenitas data hasil belajar bahasa indonesia siswa kelas III-A dan kelas III-B MIS Daarul Muqimien adalah sebagai berikut:

$$
F=\frac{70,49}{54,50}=1,293
$$

Nilai $F$ tabel pada taraf $\alpha=0,05$ dan jumlah sampel yang memiliki varians terkecil adalah 15, maka dk1 (pembilang) $=15-1=14$ dan jumlah sampel yang memiliki varians terbesar adalah 15 , maka dk2 (penyebut) $=15-1=14$, dengan 
http://jurnal.umt.ac.id/index.php/IJOEE menggunakan nilai kritik pada tabel distribusi $\mathrm{F}$ diperoleh $\mathrm{F} 0,05(14,14)=2,48$. Hal ini menunjukkan bahwa Fhitung < Ftabel atau 1,298 < 2,48 maka dapat diketahui bahwa varians kedua sampel tersebut homogen.

\section{Pengujian Hipotesis}

Hasil perhitungan interpolasi diatas diperoleh bahwa ttabel $=0,646$, dengan demikian diperoleh thitung $>$ ttabel $=6,970>1,70$, sehingga $\mathrm{H}_{1}$ ditolak dan Ho diterima. Hal ini menunjukkan bahwa terdapat erbedaan hasil Belajar siswa yang diajarkan dengan media pembelajaran dan karikatur pada keterampilan menulis Di Kelas III MIS Daarul Muqimien.

\section{KESIMPULAN DAN SARAN}

Kesimpulan yang dapat dikemukakan penulis dalam penelitian ini sesuai dengan tujuan dan permasalahan yang telah dirumuskan, serta berdasarkan hasil analisis data yang telah dilakukan adalah :

1. Terdapat perbedaan hasil belajar siswa yang diajarkan Media Pembelajaran Poster dengan hasil belajar siswa yang diajarkan dengan Media Pembelajaran Karikatur terhadap keterampilan menulis siswa kelas III MIS Daarul Muqimien ini berdasarkan hasil temuan yang menyatakan bahwa hipotesis Ha diterima yakni terdapat Perbedaan Hasil Belajar Siswa Yang Diajarkan Dengan Media Pembelajaran Poster Dan Media Pembelajaran Karikatur Pada Materi Menulis Keterampilan Menulis Di Kelas III MIS Daarul Muqimien.

2. Media karikatur lebih unggul dibandingkan dengan media poster karena dapat dilihat dari hasil penelitian yang telah dilakukan. Siswa yang diajarkan dengan media permbelajaran karikatur lebih baik dan lebih efektif dalam membuat karangan deskripsi dengan tema manfaat mengkonsumsi ikan. 
DAFTAR PUSTAKA

http://jurnal.umt.ac.id/index.php/lJOEE

Febriandari, E. I. (2016). Pengembangan Media Komik Dalam Pembelajaran Model Round Table Untuk Meningkatkan Kemampuan Menulis Cerita Siswa Kelas IV Sd. Jurnal Review Pendidikan Dasar: Jurnal Kajian Pendidikan Dan Hasil Penelitian, 2(3), 297.

Hildayanti, H., Samsuri, A. S., \& Arief, T. A. (2018). Pengaruh Penggunaan Media Poster Dalam Menulis Karangan Narasi Terhadap Hasil Belajar Siswa Pada Mata Pelajaran Bahasa Indonesia Kelas V Sd Negeri 77 Kanaeng Kabupaten Takalar. JKPD (Jurnal Kajian Pendidikan Dasar), 3(2), 518.

Kurniawati, Y. (2013). Penggunaan Media Karikatur Untuk Meningkatkan Keterampilan Menulis Karangan Narasi Pada Siswa Kelas V SDN I Kaligowon. file://I /jurnal/Yuliana\%2520Kurniawati\%252006205244125.pdf .

Megawati. (2017). Pengaruh Media Poster Terhadap Hasil Belajar Kosakata Bahasa Inggris (Eksperimen Di Sdit Amal Mulia Tapos Kota Depok). file:// jurnal/217637-pengaruh-media-poster-terhadap-hasil-bel.pdf

Nuraini, Y. (2018). Metodologi Penelitian Pendidikan. Tangerang : Fakultas Keguruan Dan Ilmu Pendidikan Universitas Muhammadiyah Tangerang.

Parendra, D. D., Wirya, N., \& Japa, I. G. N. (2013). Pemanfaatan Media Karikatur Untuk Meningkatkan Pelajaran Bahasa Indonesia Kelas V SD. Ejournal Undiksa.

Sanaky, H., AH (2015). Media Pembelajaran Interaktif - Inovatif. Yogyakarta : Kaukaba Dipantara.

Syahrudin, D. (2017). Peranan Media Gambar dalam Pembelajaran Menulis. Jurnal Pendidikan dasar: EduHumaniora, 2(1).

Tarigan, H.,G (2015). Berbicara Sebagai Suatu Keterampilan Berbahasa. Bandung: CV Angkasa.

Yarmi, G. (2017). PEMBELAJARAN MENULIS DI SEKOLAH DASAR Gusti Yarmi PGSD Universitas Negeri Jakarta. Perspektif Ilmu Pendidikan, 31(1), 1-6. 